DOI: $10.21802 / \mathrm{artm} .2020 .3 .15 .113$.

УДК 618.3-06:618.34-615.37

\title{
ВИЗНАЧЕННЯ РІВНЯ ЛАКТОФЕРИНУ ЯК МАРКЕРА РЕАЛІЗАЦІЇ ВНУТРІШНЬОУТРОБНОГО ІНФІКУВАННЯ
}

\section{O.M. Kyca}

Івано-Франківський національний медичний університет, кафедра акушерства та гінекологї ім. І.Д. Ланового, м. Івано-Франківськ, Украӥна, ORCID ID:0000-0002-8881-3756,e-mail: kusalena@ukr.net

Резюме. Розвиток вроджених інфекцій пов'язаний із наявністю внутрішньоутробного інфікування плода (анте - чи інтранатального). За таких обставин у більшості випадків джерелом інфекції для плода є мати.

Діапазон клінічних проявів внутрішньоутробної інфекції достатньо широкий. Тератогенна дія на плід призводить до різноманітних вад розвитку, стійких вроджених структурних дефектів, залишкових явищ або тривалих патологічних процесів. Досліджено, що ТORCH-інфекції залежно від періоду внутрішньоутробної агресії можуть уражати різні органи і системи, але найчастіше - нервову систему.

У ході роботи проведено інфекційний скринінг, дослідження мікробіоценозу піхви та імунологічне дослідження у 130 пацієнток із ризиком внутрішньоутробного інфікування. Обстежуючи цю категорію пацієнток на наявність специфічних антитіл IgG до парвовірусу В-19, ми сформували три досліджувані групи: I група - 64 пацієнтки із мікст-формами інфекцій TORCH-групи із наявними IgG до парвовірусу B-19; II група 41 жінка із мікст-формами інфекцій та відсутністю факторів імунного захисту до В-19V, III група - 25 пацієнток із клінічними та сонографічними проявами маніфестації внутрішньоутробної інфекції плода. Контрольну групу склали 20 осіб із фізіологічним перебігом вагітності та пологів.

Проводилось вивчення змін в імунному статусі у вагітних групи ризику щодо внутрішньоутробного інфікування. Отримано переконливі докази того, що у розвитку висхідного шляху інфікування провідну роль відіграє депресія місцевих імунологічних механізмів захисту у слизовій цервікального каналу. Запропоновано визнати гострофазовий білок сироватки крові лактоферин маркером активності імунопатологічного процесу із запальною реалізацією.

Ключові слова: вагітність, внутрішньоутробна інфекція, лактоферин.

Вступ. Група інфекційно-запальних захворювань плода і дітей раннього віку, хвороб, котрі спричинюються різноманітними збудниками, але характеризуються подібними епідеміологічними параметрами і нерідко мають однотипні клінічні прояви, називається внутрішньоутробними інфекціями (ВУІ). Ці інфекції відносяться до важких захворювань i часто впливають на рівень смертності немовлят. Актуальність проблеми ВУІ обумовлена не тільки істотними пери- та постнатальними втратами, але й тим, що у дітей, котрі перенесли важкі форми вроджених інфекцій, дуже часто розвиваються серйозні порушення здоров'я, які призводять до інвалідизації і зниження якості життя. 3 огляду на широку розповсюдженість і серйозність прогнозу можна зробити висновок, що розроблення високодостовірних методів ранньої діагностики, ефективного лікування та дієвої профілактики вроджених інфекцій є одним із першорядних завдань сучасної медицини.

Внутрішньоутробні інфекції не потребують порушення зв'язку плода з матір'ю, тобто спостерігаються без пошкодження кровоносної системи плаценти, це - вертикальний (вроджений) шлях передачі інфекції, котрий відбувається або внутрішньоутробно, або під час контакту 3 інфікованим пологовим каналом. Такий шлях передачі інфекції може бути здійснений висхідним, трансплацентарним і трансоваріальним способами під час антенатального періоду, а також контактним та аспіраційним безпо- середньо під час пологів. Антенатальне інфікування більш характерне для агентів вірусного походження (цитомегаловірус, краснуха) і внутрішньоклітинних збудників (токсоплазма, мікоплазма). Інтранатальна контамінація більш характерна для збудників бактеріальної природи. Водночас спектр потенційних збудників індивідуальний та залежить від особливостей мікробіоценозу слизових пологових шляхів матері. Найчастіше в цей період плід інфікується такими мікроорганізмами, як стрептококи (групи В), ентеробактерії, а також віруси простого герпесу типів 1 і 2, мікоплазми, уреаплазми, хламідії і інші [1].

Прогноз внутрішньоутробної трансмісії залежить від терміну гестації, в якому відбулося інфікування, особливостей збудника (патогенних та імуногенних його властивостей), типу материнської інфекції (первинна чи вторинна), функціонального стану імунної системи матері, стану фетоплацентарного бар'єру і ін. Характер пошкоджень ембріона і плода, ступінь вираженості запальних змін, а також особливості клінічної симптоматики при вроджених інфекціях залежать від цілого ряду факторів: властивостей збудника, масивності інфікування, зрілості плода, стану його захисної системи, особливостей імунітету вагітної і ін. За цих умов визначальними факторами вважають термін гестації, в котрому відбулося інфікування, та характер інфекційного процесу у вагітної (первинне інфікування чи реактивація латентної інфекції) [6] . 
Інфекція вважається первинною в тому випадку, коли організм інфікується цим збудником вперше, тобто розвиток інфекційного процесу відбувається у попередньо серонегативної пацієнтки. Якщо ж інфекційний процес розвивається внаслідок активізації збудника, який знаходився дотепер в організмі в латентному стані (реактивація) або ж через повторне інфікування (реінфекція), тоді таку інфекцію класифікують як вторинну. Встановлено, що найчастіше інфікування плода і розвиток важких варіантів ВУІ відмічається в тих випадках, коли під час вагітності жінка переносить первинну інфекцію.

В тому випадку, коли інфікування відбувається в ембріональному періоді, частіше відмічаються мимовільні викидні або виникають важкі, несумісні з життям вади розвитку плода. Проникнення збудника в організм плода в ранній фетальний період може призвести до розвитку інфекційнозапального процесу, що характеризується переважанням альтеративного компоненту 3 формуванням в пошкоджених органах фіброзно-склеротичних деформацій. Інфікування плода в пізній фетальний період може супроводжуватися запальним пошкодженням як окремих органів та систем (гепатит, кардит, менінгіт, ураження кровотворних органів 3 розвитком тромбоцитопенії, анемії та ін.), так і генералізованим ураженням [2]. Переважно під час антенатального інфікування клінічні симптоми захворювання проявляються уже в новонародженого. Тоді як під час інтранатального ураження терміни реалізації внутрішньоутробного інфекційного процесу можуть істотно зміщуватися, внаслідок чого клінічна маніфестація ВУІ може дебютувати не тільки в перші тижні життя, але навіть і в постнеонатальний період.

Обгрунтування дослідження. Вагітність це певним чином імунологічний парадокс. Будучи антигенно чужорідним для матері, плід уникає з нею імунного конфлікту завдяки репресивним механізмам, які перешкоджають материнським реакціям вродженого і адаптивного імунітету. Цьому сприяє й імунологічна неповноцінність плода, яка затримує розвиток феномена «трансплантат проти господаря», блокуючи імунні механізми, які здатні викликати пошкодження материнських тканин. Це ж створює i дефіцит резистентності плода, перешкоджаючи його адекватній реакції на інфекційні агенти, які потрапляють від матері. Вагітна, яка має повноцінні фактори захисту, стійка до більшості інфекцій, небезпечних для плода. Тому багато клінічно вагомих інфекцій, які спостерігаються у пренатальному та перинатальному періодах, відбуваються при відсутності клінічних симптомів у матері.

3 двох місяців вагітності плід реагує на мікробні агенти продукцією власних Ig M- антитіл. Підвищений рівень Ig М в пуповинній крові $є$ індикатором внутрішньоутробної інфекції плода [4]. Плід захищається від вроджених інфекцій багатьма вродженими механізмами. Одним із найважливіших $\epsilon$ плідні оболонки і амніотична рідина. Вони виступають не тільки механічним, а й секреторним бар'єром для шкідливих факторів зовнішнього середовища, в тому числі й для мікробних агентів. Важливу роль відіграють материнські IgG - імуноглобуліни. Почи- наючи 313 тижня вагітності, вони безперервно потрапляють до плода через плаценту. До моменту народження здорової дитини основна маса антитіл представлена материнськими IgG. Захисний спектр їх досить широкий i направлений проти інфекційних агентів. Вагітні жінки схильні до різноманітних інфекційних захворювань, але більшість інфекцій не мають безпосереднього впливу на плід - їх збудники не потрапляють у кров матері і материнську частину плаценти. Проте, є і такі інфекції, коли збудник тривало і безсимптомно циркулює. Це характерно для персистентних вірусів, які активуються при вагітності, провокуючи у вагітної ендогенні (вторинні) рецидиви безсимптомної інфекції. Ще більше небезпечні екзогенні віруси. Такі інфекції виникають на нульовому імунологічному фоні, можуть перебігати безсимптомно і слугують сигналом первинного контакту вагітних жінок з інфекційним агентом [7].

Слідом за ураженням плаценти інфекційні агенти трансплацентарно проникають через пупкову вену в організм плода, викликаючи його пошкодження. Чим раніше інфікується плід - тим важчі наслідки.

У другій половині вагітності прояви інфекцій залежать від природи мікробного агента. Для пошкоджень характерний запальний синдром. Запалення плаценти (плацентит) призводить до серйозних наслідків, що пов'язані із порушенням кровопостачання і тканинною гіпоксією плода [5].

Наявність під час вагітності у жінки хронічних інфекційно-запальних захворювань генітальної та екстрагенітальної сфери призводить до значного дисбалансу в системі «мати-плацента-плід», викликаючи порушення в механізмах реалізації програми внутрішньоутробного розвитку [3]. Слід зазначити, що при вагітності в силу особливого функціонального стану імунної системи виникає різноманіття клінічних проявів внутрішньоутробного інфікування, що створює значні труднощі для профілактики, ранньої діагностики і своєчасного лікування цих процесів. Перспективним на сьогодні залишається вивчення особливостей розвитку імунозапального процесу в патогенезі ВУІ, оцінювання значимості дисбалансу індукторів міжклітинних взаємовідносин цитокінів, які регулюють розвиток як фізіологічної імуносупресії при вагітності, так і активації імунної системи у відповідь на антигенну стимуляцію із вогнищ хронічного запалення.

Мета дослідження. Дослідити певні критерії активності системи імунітету у жінок із внутрішньоутробним інфікуванням плода.

Матеріали і методи. Дослідження проводились на базі кафедри акушерства та гінекології ІваноФранківського національного медичного університету (обласний перинатальний центр, відділення невиношування міського пологового будинку, центр планування сім’ї м. Івано-Франківськ).

У ході роботи було проведено ретельний інфекційний скринінг 130 пацієнток (загальна група) iз високим ступенем імовірного внутрішньоутробного інфікування шляхом бактеріоскопічного, бактеріологічного обстеження, а також ідентифікації збудників TORCH-групи 
методом імуноферментного аналізу та ДНКполімеразно-ланцюгової реакції на аналізаторі "Stat Fax 303 Plus" (США) за допомогою наборів реагентів “ProCon IL-1 $\beta$ ”(ТОВ “Протеїновий контур”, Росія), "Accucyte Human IL-8" (Cytimmune Sciences Inc., СШA), "Biotrak IL-10 human ELISA system" (Amersham Pharmacia Biotech, Великобританія) у сертифікованій лабораторії м. Івано-Франківська «Діамеб». Із усіх пацієнток у 35 вагітних було діагностовано поєднану вірусну інфекцію, у 35 мікст-форми бактеріальної інфекції, у 35 жінок вагітність ускладнилась наявністю змішаної віруснобактеріальної інфекції.

Діагностична програма також передбачала обстеження цієї категорії пацієнток на наявність специфічних антитіл IgG до парвовірусу В-19, що дозволило сформувати три досліджувані групи: I група - 64 пацієнтки із мікст-формами інфекцій TORCH-групи, у яких шляхом серологічного обстеження сироватки крові було виявлено IgG до парвовірусу В-19; II група - 41 жінка із мікстформами інфекцій та серонегативними даними щодо наявності факторів імунного захисту до В-19V, III група - 25 пацієнток із клінічними та сонографічними проявами маніфестації внутрішньоутробної інфекції плода. Контрольну групу склали 20 осіб із фізіологічним перебігом вагітності.

У ході проведення дослідження була здійснена додаткова діагностична програма 3 використанням методу імуноферментного аналізу щодо оцінки цитокінового профілю у цервікальному слизі (рівень інтерлейкінів (IL) IL-1 $\beta$, IL-4, IL-6, TNF$\alpha$, IFN- $\gamma$ ) та визначення рівня лактоферину $\mathrm{y}$ сироватці крові матері та амніотичній рідині. Визначення концентрації лактоферину виконувалося на тест-системах виробництва ЗАО “Вектор-БЕСТ” по інструкції виробника у міжкафедральній лабораторії Івано-Франківського національного медичного університету.

Статистичну обробку отриманого матеріалу здійснювали за допомогою персонального комп'ютера та прикладної програми для роботи із електронними таблицями Microsoft Excel за допомогою пакету “STATISTICA 6,0”.

Лактоферин виступає регулятором концентрації вільних іонів заліза в крові і секретах, регулює абсорбцію заліза в шлунково-кишковому тракті. Крім того, макромолекула лактоферину володіє ділянками зв'язування для бактеріальних ендотоксинів, цитотоксинів, ліпополісахаридів, гепарину і інших молекул. Як імунотропний білок лактоферин бере участь у регуляції клітинної і гуморальної ланки імунітету, діючи через рецептори імунокомпетентних клітин, інтерлейкіни та систему комплемента.

\section{Результати}

досліджень.

внутрішньоутробного інфікування представлена більш широким спектром мікроорганізмів, серед яких значна роль належить ентеровірусам, хламідіям, уреаплазмам, мікоплазмам, а також вірусам грипу, парвовірусам i ряду інших інфекційних агентів. Особливо хочеться відмітити той факт, що потенційна загроза внутрішньоутробної трансмісії інфек- ційних агентів від матері до іiі майбутньої дитини істотно зростає в тих випадках, коли жінка має обтяжений соматичний чи акушерсько-гінекологічний анамнез. При цьому факторами ризику внутрішньоутробного інфікування є запальні захворювання урогенітального тракту у матері, несприятливий перебіг вагітності (важкі гестози, загроза переривання вагітності, патологічний стан фетоплацентарного бар'єру, інфекційні захворювання).

Результати наших власних досліджень свідчать про високий рівень внутрішньоутробного інфікування: на прегравідарному етапі виявлено низьку інфікованість тільки у 21 жінки $((16,15 \pm 3,23) \%)$, у кожної п'ятої пацієнтки - асоціації представників умовнопатогенної мікрофлори (E.coli, St.aureus, St. Epidermalis, Enterococ. faecalis, Str. Angemaliticus) були у критичному мікробному числі $\left(10^{4}-10^{6} \mathrm{КУО/мл).}\right.$

Серопозитивність пацієнток відносно тільки одного із вивчених збудників TORCH-групи практично не зустрічалася, поєднання герпесвірусної та цитомегаловірусної інфекцій відмічено у 29 жінок $((22,31 \pm 3,66) \%)$, а також їх асоціації з бактеріальними збудниками у 58 жінок $((44,62 \pm 4,36) \%)$, зокрема 3 хламідіями - у $28(21,54 \pm 3,61) \%$. Поєднання 3-х та більше інфекційних чинників відмічено саме у пацієнток, серонегативних до парвовірусу В-19, у третини з них відмічено ураження вірусом простого герпесу та цитомегаловірусу, також варто відзначити у цій групі високий відсоток гарднерельозу.

Бактеріальний вагіноз був верифікований у 17 пацієнток I групи $((26,56 \pm 5,52) \%)$, у 19 осіб $((46,34 \pm 7,79) \%)$ II групи, та у $7(28,0 \pm 8,98) \%$ - у III групі при наявності нормального біотопу піхви у контролі $(\mathrm{p}<0,05)$. Кольпіт виявлено у $25 \quad((39,06$ $\pm 6,10) \%$ ) жінок I групи, у $24((58,54 \pm 7,69) \%)$ - II групи та у 7жінок $((28,0 \pm 8,98) \%)$ - III групи, патологію шийки матки діагностовано практично у кожної другої пацієнтки проти даних контролю $(\mathrm{p}<0,05)$.

У нашій роботі у 80 жінок було проведено оцінку рівня лактоферину у сироватці крові та амніотичній рідині як одного 3 імунологічних показників запальної відповіді, в результаті чого встановлено у 72 жінок $((90,00 \pm 3,35) \%)$ достовірне підвищення його концентрації у 1,5 рази порівняно 3 контролем $(\mathrm{p}<0,05)$ із одночасним зростанням рівня IL-1 $\beta$. При обстеженні амніотичних вод у $69((86,25 \pm 3,85) \%)$ пробах також встановлено підвищення рівня лактоферину, у $11((13,75 \pm 3,76) \%)$ пробах - зниження його вмісту поряд із низькими показниками IL-1 $\beta(\mathrm{p}<0,05)$. Особливо низький рівень цього показника у амніотичній рідині відмічено при вагітності 3 реалізацією внутрішньоутробної інфекції: у 6 пробах $((40,0 \pm 12,65) \%)$ iз 15 , отриманих при розродженні вагітних III групи, рівень лактоферину демонстрував нижчі, більше як у 9 раз, показники проти даних контролю $(\mathrm{p}<0,05)$.

Обговорення результатів. Проводячи наші дослідження, ми визначили основні фактори ризику внутрішньоутробного інфікування: висока частка інфекційно-запальних захворювань урогенітальної сфери $((33,08 \pm 4,13) \%)(\mathrm{OR}-2,1 ; 95 \%$ CI: $(1,2-3,0))$; 


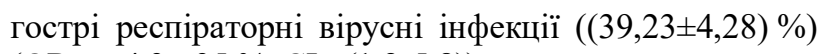
(OR - 4,3; 95 \% CI: $(1,2-5,8))$; загроза переривання вагітності $((36,15 \pm 4,21) \%)$ і високий рівень гестаційної анемії $((26,92 \pm 3,89) \%)(\mathrm{OR}-5,3 ; 95$ \% CI: $(2,4-$ $8,8))$, багатоводдя $((49,23 \pm 4,38) \%)(\mathrm{OR}-6,4 ; 95 \% \mathrm{CI}$ : $(3,8-11,6))$ та порушення мікробіоценозу статевих

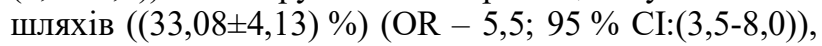
значима частка плацентарної дисфункції $((23,08 \pm 3,70) \%)$. Отримані результати аналізу перинатальних наслідків у жінок із мікст-інфекціями вказують на вагомий відсоток репродуктивних втрат $((22,31 \pm 3,65) \%)$, мертвонародження $((10,77 \pm 2,72) \%)$, недоношування та передчасних пологів $((27,69 \pm 3,92) \%)$.

Вивчаючи вміст лактоферину у сироватці крові та амніотичній рідині досліджуваних груп пацієнток, ми отримали наступні дані: у пацієнток I-ї групи середній рівень лактоферину сироватки крові становив $(1564,0 \pm 12,8)$ нг/мл та дещо вищий $(1986,0 \pm 10,2)$ нг/мл у амніотичній рідині, у ІІ-й групі - $(2086,0 \pm 18,2)$ нг/мл та $(988,0 \pm 6,2)$ нг/мл - відповідно, у ІІІ-й групі відмічено зростання лактоферину у сироватці крові $(2186,0 \pm 16,4)$ нг/мл та різке зменшення $(368,0 \pm 12,6)$ нг/мл у навколоплідних водах порівняно з групою контролю - $(1388,0 \pm 12,0)$ нг/мл та $(3488,0 \pm 18,8)$ нг/мл у сироватці крові та амніотичній рідині відповідно.

Результатом цього наукового дослідження став наступний діагностичний критерій: при збільшенні концентрації лактоферину у сироватці крові втричі та низьких показниках його у амніотичних водах можна прогнозувати реалізацію та розвиток внутрішньоутробного інфікування плода ( $\mathrm{Se}=73,08 \%$; 95\% CI: 56,03-90,13, p<0,001). Високі рівні лактоферину у сироватці крові є критерієм активності системи імунітету, чутливим індикатором вираженості цитолітичного процесу у фетоплацентарному комплексі, що дозволяє визнати його маркером активності імунопатологічного процесу із запальною реалізацією.

Слід відмітити, що зростання рівня IL-1 $\beta$ в амніотичній рідині має зворотну кореляцію із рівнем цього показника у цервікальному слизі, що характеризує дисбаланс механізмів місцевого імунного захисту у досліджуваної категорії пацієнток.

Висновки. Формування правильної статевої поведінки, починаючи з підліткового віку, усунення факторів хаотичного статевого життя, санація хронічних вогнищ інфекції, своєчасна діагностика ризику інфікування вагітної на преконцепційному етапі дає можливість зменшити ризик виникнення внутрішньоутробного інфікування плода.

Вроджені інфекції і надалі залишаються одними із найбільш серйозних захворювань у новонароджених і дітей раннього віку. Різноманітна етіологія та однотипність симптомів утруднюють клінічну верифікацію ВУІ, чим і визначається необхідність своєчасного проведення спеціальних досліджень.

Вивчаючи вміст лактоферину у сироватці крові вагітної - гострофазового білка, що володіє імуностимулюючими властивостями, бактерицидною дією, має здатність впливати на продукцію прозапальних цитокінів - хочеться визнати його маркером активності імунопатологічного процесу із запальною реалізацією, так як по зміні його концентрації в біологічних середовищах вагітної можна спрогнозувати реалізацію та розвиток внутрішньоутробного інфікування у плода.

\section{References:}

1. Dadval V, Bhatt RK. Intrauterine Fetal Infections:DoAble Approaches.Journal of Fetal Medicine.2020; 7:5-8.

2. Kuzmyn VN, Arslanian KN, Kharchenko EY. Sovremennyi vzghliad na problemu vnutryutrobnoi infektsyi. Lechashchyi vrach. 2016; 3:44-6.

3. Mateiko HB, Matvisiv MV. Ryzyk infikuvannia ploda i novonarodzhenoho u vahitnykh zhinok z HBV- i HCV- infektsiieiu. Infekts. khvoroby. 2017; 2(88):914.

4. Maianskyi AN. Infektsyonnye vzaymootnoshenyia v systeme «mat- plod» (chast I). Voprosy diahnost. v pediatr. 2015; 4(1):12-9.

5. Chermak II, Martynova DA, Kaliuzhna VM. Osoblyvosti perynatalnoho dohliadu u patsiientok iz hrupy ryzyku vnutrishnoutrobnoho infikuvannia ploda/ Aktual. Pytan. Ped., Akush. ta Hinek. 2015; 1:196-8.

6. Shcherbyna NA, Vyhivska LA, Kapustnyk NV. Vnutrishnoutrobni infektsii - prychyna patolohichnykh staniv perynatalnoho periodu. Perynatol. y pedyatr.2016; 2(66):65-70.

7. Shcherbyna NA, Vyhivska LA, Radzishevska YeB. Prohnozuvannia realizatsii vnutrishnoutrobnoho infikuvannia u novonarodzhenykh. Visnyk problem biolohii i medytsyny.2018; 1(142):217-22.

\section{УДК 618.3-06:618.34-615.37}

\section{ОПРЕДЕЛЕНИЕ УРОВНЯ ЛАКТОФЕРРИНА КАК МАРКЕРА РЕАЛИЗАЦИИ ВНУТРИ- УТРОБНОГО ИНФИЦИРОВАНИЯ}

\section{E.M. Kyca}

Ивано-Франковский государственный медицинский университет, кафедра акушерства и гинекологии им. И.Д. Ланового, г. Ивано-Франковск, Украина, ORCID ID: 0000-0002-8881-3756,

e-mail:kusalena@ukr.net

Резюме. Развитие врожденных инфекций связано с наличием внутриутробного инфицирования плода (анте- или интранатального). При этом в большинстве случаев источником инфекции для плода является мать.

Диапазон клинических проявлений внутриутробных инфекций достаточно широк. Тератогенное действие на плод приводит к таким проблемам, как разнообразные пороки развития, стойкие врожденные структурные дефекты, остаточные явления или длительные патологические процессы. Доказано, что TORCH-инфекции в зависимости от периода внутриутробной агрессии могут поражать различные органы и системы, но наиболее часто - нервную систему.

Во время исследования проведен инфекционный скрининг, исследование микробиоценоза вла- 
галища и иммунологическое исследование у 130 пациенток с риском внутриутробного инфицирования и, кроме того, проводя обследование данной категории пациенток на наличие специфических антител $\mathrm{IgG}$ к парвовирусу В-19, мы сформировали три исследуемые группы: I группа - 64 пациентки с микстформами инфекций TORCH-группы и наличием IgG к парвовирусу В-19; II группа - 41 женщина с микстформами инфекций и отсутствием факторов иммунной защиты к B-19V, III группа - 25 пациенток с клиническими и сонографическими проявлениями манифестации внутриутробной инфекции плода.

Проведено изучение изменений в иммунном статусе у беременных группы риска по внутриутробном инфицировании. Получены убедительные доказательства того, что в развитии восходящего пути инфицирования ведущую роль занимает депрессия местных иммунологических механизмов защиты в слизистой цервикального канала. Предложено признать острофазный белок лактоферрин маркером активности иммунопатологического процесса с воспалительной реализацией.

Ключевые слова: беременность, внутриутробная инфекция, лактоферрин.

UDC 618.3-06:618.34-615.37

DETERMINATION OF LACTOFERRINE LEVEL AS A MARKER OF IMPLEMENTATION OF INTRAUTERINE INFECTION

\section{O.M. Kusa}

National Medical University, Department of Obstetrics and Gynecology, Ivano-Frankivsk,

Ukraine Ivano-Frankivsk,

ORCID ID: 0000-0002-8881-3756,

e-mail:kusalena@ukr.net

Abstract. The development of congenital infections is associated with intrauterine infection of the fetus (ante- or intranatal). In this case, in the vast majority of cases, the source of infection for the fetus is the mother.

The range of clinical manifestations of intrauterine infections is quite wide. Teratogenic effects on the fetus or embryo, such as various malformations, persistent congenital structural defects, residual effects or prolonged pathological process are some of the main problems caused by infection of the fetus in utero. It has been studied that TORCH infections, depending on the period of intrauterine aggression, can affect different organs and systems, but most often the nervous system.

Intrauterine infection of the fetus depends on the type and virulence of the pathogen, the intensity of con- tamination, the stage of the disease, ways of penetration of the infection into the fetal body, immunoreactivity of the body, gestational age in infection. It is rather difficult to diagnose and treat intrauterine infection. This is due to the following reasons: polyetiology, difficulties in antenatal diagnosis, multifactorial specific and nonspecific influence of the infectious agents on the fetus.

130 patients at risk of intrauterine infection were included in the study, 35 of them had mixed forms of viral infections, 35 pregnant women were diagnosed with mixed forms of bacterial infection, and 35 women had mixed viral and bacterial infections. Infectious screening at the pre-gestational stage and in the dynamics of pregnancy allowed to identify a combination of three or more urogenital infections of mixed origin in $8(51.42 \pm 8.28) \%$ of women of group I, in $16(28.57 \pm 7.85) \%$ of women of group II, and in $5(54.28 \pm 9.60) \%$ of women of group III. It has been established that combined forms of infection in the mother adversely affect the fetus and the baby's condition.

According to the results of our clinical studies, patients with various forms of infection are at high risk for obstetric and perinatal complications, and the probability of manifestation and damage to the fetus depends on the term of infection and a combination of leading infectious factors. In the course of the study, based on an integrated approach, the impact of mixed forms of viral and bacterial infection on pregnancy and perinatal consequences was assessed, i.e. the main risk factors for intrauterine infection were identified. Lactoferrin is a multifunctional protein involved in inflammatory and pathological processes in general. The non-exhaustive list of lactoferrin characteristics includes antibacterial and antiviral properties, due to the ability to bind metal ions, as well as anticancer and antioxidant activity, regulation of cell growth and differentiation, anti-inflammatory and immunomodulatory properties and it refers to nonspecific protective factors. The concentration of lactoferrin in human blood often varies in different diseases, so its definition has recently become quite widespread in laboratory diagnosis.

The changes in the immune status of pregnant women at risk for intrauterine infection were studied. It was proved that the depression of local immune defense mechanisms in the cervical mucosa plays a leading role in the development of the ascending pathway of infection. It was proposed to consider the acute phase serum protein lactoferrin as a marker of the activity of immunopathological process with inflammatory realization. lactoferrin.

Keywords: pregnancy, intrauterine infection,

Стаття надійшла вредакцію 26.08.2020 р. 